\title{
ANALISIS KOMUNIKASI PROGRAM ASURANSI USAHA TANI PADI DAN PERSEPSI PETANI DI KABUPATEN SOLOK
}

\section{Analysis of Communication Insurance Programs rice farming Business and Farmer Perception in Solok District}

\section{Yenny Oktavia, Zednita Azriani}

Fakultas Pertanian, Universitas Andalas

*email koresponden: yennyoktaviafp@gmail.com

\begin{abstract}
Abstrak
Sektor pertanian khususnya tanaman pangan sering dihadapkan kepada resiko kegagalan panen. Hal ini disebabkan ka rena perubahan iklim dan bencana yang dia lami sektor pertanian. Asuransi Usa ha Tani Padi(AUTP) merupakan suatu upaya untuk mengatasi resiko kegagalan panen bagi petani. Penelitian inibertujuan untuk mengidentifikasi tingk at persepsi petani terhadap Program Asuransi Usaha Tani Padidi Kabupaten Solok, dan menganalisis ko m unika si AUTP da lam ran gka meningkatkan perencanaan komunikasi program AUTP di Kabupaten Solok. Analisis data yang digunakan da lam penelitia n ini a dalah a nalisis deskriptif kualitatif. Hasil penelitia n menunjukkan bahwa 1). Persepsi petani terhadap progra $m$ AUTP di Kabupaten Solok secara umum a dalah kurang baik, yang direfleksikan dengan kurang baiknya persepsi petani terhadap sosialisasi AUTP, polis AUTP, klaim AUTP, dan manfaat AUTP. Hasilpenelitian menunjuk kan bahwa informasi ya ng diberikan cukup sesuai dengan kebutuhan dan relevan dengan permasalahan yang dihadapi petani, namun ma sih kurangnya sosialisasi program, sehingga ketentuan-ketentuan pada mekanisme program belum terakomodasi sesuai keinginan petani. Artinya, program AUTP y ang a da selama inibelum diinisiasi dari sistem sosial masyarakat, khususnya petani, tujuan dan ketentuan program yang ada saat ini ha nya merupakan hasil ketetapan dari pemerintah.
\end{abstract}

Kata kunci: Perencanaan komunikasi, persepsi, a suransi usahatani padi, analisis program

\begin{abstract}
The agricultural sector, especiallyfood crops, is oftenfaced with the risk of cropfailure. It is caused due to chang es in climate and disasters are experienced sector of agriculture. Paddy Farming Business Insurance (AUTP) is an effort to overcome the risk of crop failureforfarmers. This research aims to identify the leveloffarmers' perceptions of the Rice Farmer Business Insurance Program in SolokDistrict, and analyze the AUTP communication in order to improve the AUTP program communication planning in Solok Regency. Analysis of the data used in this study is a qualitative descriptive analysis. The results of the studyindicate that 1). Perception offarmers on the program AUTP in the District of Solok in general is less good, which is reflected by the lack of goodperception of farmers towards socialization AUTP, AUTP policy, claims AUTP, and benefits AUTP. Results of the study show that the information that is given sufficient according to the needs and relevant to the issues thatfaced by farmers, but still lack the socialization program, so that the provisions on the mechan ism of the program have not been accommodated according the wishes offarmers. That is, AUTP programs that exist for this has notbeen initiated from the system of social communities, particularly farmers, objectives and provisions of the program that there currently is only a result statutes of government .
\end{abstract}

Keywords : planning communication, perception, insurance farming rice, program analize 


\section{PENDAHULUAN}

Usaha pencapaian target swasembada pangan khususnya usahatani padi dihadapkan pada risiko ketidakpastian sebagai akibat dampak negatif perubahan iklim yang merugikan petani (Pasaribu, 2009). Risiko produksi terjadi karena fluktuasi hasil akibat berbagai faktor yang sulit diduga (perubahan iklim, cuaca ekstrim, banjir, kekeringan, dan serangan OPT). Petani sebagai pelaku utama usahatani menerima dampak dan risiko yang paling besar akibat bencana terkait iklim. Risiko yang harus ditanggung petani antara lain: risiko produksi, harga, pasar, finansial, teknologi, sosial, hukum, dan manusia. Petani menghadapi berbagai akibat dari gagal panen atau produksi rendah yang berpengaruh terhadap pengembalian modal kerja, pengusahaan modal baru, pendapatan rumah tangga, biaya hidup lain, dan sebagainya (Pasaribu, et al, 2010). Oleh karena itu perlu proteksi formal bagi petani dalam menekan risiko terkait iklim diantaranya melalui mekanisme asuransi yaitu pengalihan risiko-risiko tersebut kepada perusahaan asuransi, dengan biaya premi yang relatif kecil.

Asuransi Usaha Tani Padi (AUTP) merupakan suatu upaya untuk mengatasi resiko kegagalan panen bagi petani. AUTP bertujuan memberikan perlindungan kepada petani jika terjadi gagal panen sebagai akibat resiko banjir, kekeringan, dan serangan oraganisme pengganggu tumbuhan. Mengalihkan kerugian akibat resiko banjir, kekeringan dan serangan OPT melalui pihak lain yakni pertanggungan asuransi. Sasaran penyelenggaraan AUTP adalah terlindunginya petani dengan memperoleh ganti rugi jika mengalami gagal panen.

Kabupaten Solok merupakan daerah sentra penghasil beras terbesar di Sumatera Barat. Program AUTP juga sudah berjalan di Kabupaten Solok sejak tahun 2015 dan merupakan kabupaten yang termasuk menyalurkan premi AUTP yang besar, yaitu sekitar $1.395,17$ ha sawah. Peserta definitif dari premi AUTP merupakan yang terbanyak, yaitu sebesar 123 kelompok tani. Namun realisasi premi tersebut masih dibawah target yang direncanakan oleh Dinas Pertanian Tanaman Pangan. Realisasi AUTP yang masih baru, yaitu baru berkisar sekitar 2 tahun masih belum mendapatkan respon yang berarti dari petani.

Pelaksanaan AUTP dilakukan dengan menggunakan pendekatan program, artinya pemerintah memunculkan program tersebut kepada petani melalui kelompok tani lewat Dinas Pertanian Tanaman Pangan. Pengalaman pembangunan pertanian selama ini menunjukkan bahwa kebijakan pemerintah yang menggunakan pendekatan program cenderung gagal dan tidak berkelanjutan. Petani cenderung pasif dalam menanggapi program dan tidak memiliki motivasi untuk melanjutkan program tersebut.

Perencanaan Program Komunikasi (PPK) merupakan upaya membuat rancangan pelaksanaan suatu program komunikasi untuk mengkampanyekan, menyosialisasikan, atau mempromosikan suatu "produk" (program, barang, jasa, atau lembaga) kepada khalayak sasarannya dengan harapan tercapainya tujuan PPK yang telah ditetapkan. (Windahl, Benno , \& Jean , 1992) menyebutkan bahwa salah satu karakteristik perencanaan komunikasi adalah kegiatan komunikasi yang direncanakan dari bawah (bottom-up) bukan komunikasi yang dilakukan dari atas (top down), artinya, isi pesan komunikasi didasarkan atas hasil penggalian terhadap aspirasi dan kebutuhan khalayak. Ia juga menyebutkan bahwa komunikasi harus dilihat dari kepentingan penerima, bukan dari kepentingan pengirim. Hasil penelitian (Azriani, Usman, \& Paloma, 2017) mengatakan bahwa program AUTP dilaksanakan pemerintah secara top down, bukan bottom up. Kegagalan pelaksanaan AUTP juga karena sosialisasi oleh dinas pertanian dan tanaman pangan belum optimal. Hal ini diduga karena perencanaan komunikasi yang belum tepat sasaran, di mana kegiatan belum sepenuhnya didasarkan pada kepentingan penerima, dalam hal ini petani.

Berdasarkan kondisi diatas, maka diperlukan perencanaan komunikasi untuk mensosialisasikan 
program AUTP di Kabupaten Solok, melalui analisis program AUTP agar dapat diterima petani dengan baik, tingkat kepuasan petani terhadap program tersebut juga terpenuhi, dan sebagai dasar bagi penelitian selanjutnya dalam mengembangkan strategi asuransi pertanian yang berkelanjutan. Tujuan dari penelitian ini adalah: 1. Menggambarkan persepsi petani terhadap AUTP di Kabupaten Solok. 2. Menganalisis program komunikasi AUTP di Kabupaten Solok

\section{METODE PENELITIAN}

Usaha pencapaian target swasembada pangan khususnya usahatani padi dihadapkan pada risiko ketidakpastian sebagai akibat dampak negatif perubahan iklim yang merugikan petani (Pasaribu, 2009). Risiko produksi terjadi karena fluktuasi hasil akibat berbagai faktor yang sulit diduga (perubahan iklim, cuaca ekstrim, banjir, kekeringan, dan serangan OPT). Petani sebagai pelaku utama usahatani menerima dampak dan risiko yang paling besar akibat bencana terkait iklim. Risiko yang harus ditanggung petani antara lain: risiko produksi, harga, pasar, finansial, teknologi, sosial, hukum, dan manusia. Petani menghadapi berbagai akibat dari gagal panen atau produksi rendah yang berpengaruh terhadap pengembalian modal kerja, pengusahaan modal baru, pendapatan rumah tangga, biaya hidup lain, dan sebagainya (Pasaribu, et al, 2010). Oleh karena itu perlu proteksi formal bagi petani dalam menekan risiko terkait iklim diantaranya melalui mekanisme asuransi yaitu pengalihan risiko-risiko tersebut kepada perusahaan asuransi, dengan biaya premi yang relatif kecil.

Asuransi Usaha Tani Padi (AUTP) merupakan suatu upaya untuk mengatasi resiko kegagalan panen bagi petani. AUTP bertujuan memberikan perlindungan kepada petani jika terjadi gagal panen sebagai akibat resiko banjir, kekeringan, dan serangan oraganisme pengganggu tumbuhan. Mengalihkan kerugian akibat resiko banjir, kekeringan dan serangan OPT melalui pihak lain yakni pertanggungan asuransi. Sasaran penyelenggaraan AUTP adalah terlindunginya petani dengan memperoleh ganti rugi jika mengalami gagal panen.

Kabupaten Solok merupakan daerah sentra penghasil beras terbesar di Sumatera Barat. Program AUTP juga sudah berjalan di Kabupaten Solok sejak tahun 2015 dan merupakan kabupaten yang termasuk menyalurkan premi AUTP yang besar, yaitu sekitar 1.395,17 ha sawah. Peserta definitif dari premi AUTP merupakan yang terbanyak, yaitu sebesar 123 kelompok tani. Namun realisasi premi tersebut masih dibawah target yang direncanakan oleh Dinas Pertanian Tanaman Pangan. Realisasi AUTP yang masih baru, yaitu baru berkisar sekitar 2 tahun masih belum mendapatkan respon yang berarti dari petani.

Pelaksanaan AUTP dilakukan dengan menggunakan pendekatan program, artinya pemerintah memunculkan program tersebut kepada petani melalui kelompok tani lewat Dinas Pertanian Tanaman Pangan. Pengalaman pembangunan pertanian selama ini menunjukkan bahwa kebijakan pemerintah yang menggunakan pendekatan program cenderung gagal dan tidak berkelanjutan. Petani cenderung pasif dalam menanggapi program dan tidak memiliki motivasi untuk melanjutkan program tersebut.

Perencanaan Program Komunikasi (PPK) merupakan upaya membuat rancangan pelaksanaan suatu program komunikasi untuk mengkampanyekan, menyosialisasikan, atau mempromosikan suatu "produk" (program, barang, jasa, atau lembaga) kepada khalayak sasarannya dengan harapan tercapainya tujuan PPK yang telah ditetapkan. (Windahl, Benno , \& Jean , 1992) menyebutkan bahwa salah satu karakteristik perencanaan komunikasi adalah kegiatan komunikasi yang direncanakan dari bawah (bottom-up) bukan komunikasi yang dilakukan dari atas (top down), artinya, isi pesan komunikasi didasarkan atas hasil penggalian terhadap aspirasi dan kebutuhan khalayak. Ia juga menyebutkan bahwa komunikasi harus dilihat dari kepentingan penerima, bukan dari kepentingan pengirim. Hasil penelitian (Azriani, 
Usman, \& Paloma, 2017) mengatakan bahwa program AUTP dilaksanakan pemerintah secara top down, bukan bottom up. Kegagalan pelaksanaan AUTP juga karena sosialisasi oleh dinas pertanian dan tanaman pangan belum optimal. Hal ini diduga karena perencanaan komunikasi yang belum tepat sasaran, di mana kegiatan belum sepenuhnya didasarkan pada kepentingan penerima, dalam hal ini petani.

Berdasarkan kondisi diatas, maka diperlukan perencanaan komunikasi untuk mensosialisasikan program AUTP di Kabupaten Solok, melalui analisis program AUTP agar dapat diterima petani dengan baik, tingkat kepuasan petani terhadap program tersebut juga terpenuhi, dan sebagai dasar bagi penelitian selanjutnya dalam mengembangkan strategi asuransi pertanian yang berkelanjutan. Tujuan dari penelitian ini adalah: 1. Menggambarkan persepsi petani terhadap AUTP di Kabupaten Solok. 2. Menganalisis program komunikasi AUTP di Kabupaten Solok.

\section{Pengumpulan Data}

Jenis data yang digunakan dalam penelitian ini adalah data kerat lintang (cross section). Data yang digunakan dari penelitian ini terdiri dari data primer dan data sekunder. Data primer diperoleh dari key informan dan responden melalui daftar wawancara dan kuesioner. Data sekunder diperoleh dari studi literatur, laporan dinas pertanian, pihak Asuransi Jasindo. Data yang dikumpulkan untuk penelitian ini adalah: identitas petani, data usaha tani, data kepuasan petani terhadap adanya asuransi pertanian, data willingness to pay petani terhadap asuransi pertanian.

\section{Analisis Data}

Pengolahan data dilakukan setelah semua data yang dibutuhkan terkumpul. Analisis data dilakukan secara kualitatif dan kuantitatif. Metode kualitatif disajikan dengan mengintrepetasikan dan mendeskripsikan data yang diperoleh. Sedangkan data kuantitatif yang diperoleh akan ditabulasikan berdasarkan aktivitas-aktivitas. Metode analisis yang digunakan pada penelitian ini yaitu analisis deskriptif, analisis yang digunakan untuk melihat persepsi petani terhadap program AUTP adalah skala Likert, Skor penilaian terhadap pernyataan responden adalah sangat setuju dengan nilai 5 , setuju dengan nilai 4 , ragu-ragu dengan nilai 3 , tidak setuju dengan nilai 2, dan sangat tidak setuju dengan nilai 1 . Dengan cara perhitungan skor sebagai berikut: Jumlah Skor Tiap Kriteria :

Capaian Skor $(5,4,3,2,1)$ x Jumlah Responden......(1)

Total Skor : $\sum$ Jumlah Skor Tiap Kriteria

Rata-rata Total Skor : Total Skor / Jumlah

Responden

Penentuan tingkat persepsi dikelompokkan dengan skala Likert menjadi lima kategori yaitu sangat buruk, buruk, kurang baik, baik dan sangat baik, dan dikategorikan berdasarkan interval. Menurut Mangkuatmojo (1997:37) nilai interval dapat diperoleh dari rumus sebagai berikut :

Interval $(\hat{i})=\frac{\text { Nilai Var.terting } \text { i }- \text { Nilai } \text { Var.Terendah }}{\text { Banyak } \text { Kelas }(k)}$

$\operatorname{Interval}(\hat{i})=\frac{5-1}{5}=0,8$

Tabel 1. Tingkat Persepsi Berdasarkan Interval Nilai Tnggapan

\begin{tabular}{|c|c|c|}
\hline $\begin{array}{l}\text { Interval } \\
\text { Tanggapan }\end{array}$ & Nilai & Tingkat Persepsi \\
\hline $1,00-1,80$ & & Sangat buruk \\
\hline $1,81-2,60$ & & Buruk \\
\hline $2,61-3,40$ & & Kurang Baik \\
\hline $3,41-4,20$ & & Baik \\
\hline $4,21-5,00$ & & Sangat Baik \\
\hline
\end{tabular}




\section{HASIL DAN PEMBAHASAN}

\section{Analisis Tingkat Persepsi Petani terhadap Asuransi Usaha Tani Sawah di Kabupaten Solok}

Program Asuransi Usahatani Padi (AUTP) merupakan upaya perlindungan usahatani oleh pemerintah untuk mengatasi kerugian petani dalam melakukan usahatani khususnya komoditi padi. Agar program ini dapat berjalan dengan baik, tentunya peserta program AUTP yakni petani diharapkan memiliki persepsi yang baik pula. Persepsi petani terhadap program AUTP dilihat berdasarkan variabel sosialisasi, manfaat dan potensi AUTP di Kabupaten Solok. Menurut Schivinski. B; Dabrowski, D (2016) , hasil studi empiris menunjukkan bahwa komunikasi media sosial yang dihasilkan oleh pengguna memiliki pengaruh positif pada ekuitas merek dan sikap terhadap merek, yang terbukti memiliki pengaruh positif pada niat pembelian.

\section{Padi (AUTP)}

Sosialisasi Asuransi Usaha Tani Usaha Tani

Untuk melihat persepsi petani terhadap sosialisasi AUTP, variabel yang diamati dalam penelitian ini terkait dengan pemberian informasi, manfaat sosialisasi dan frekuensi sosialisasi yang dilakukan untuk memberikan pengetahuan kepada petani mengenai program AUTP. Pada variabel sosialisasi, untuk mengetahui persepsi responden terhadap program. AUTP terdapat empat indikator pernyataan yang dapat dilihat pada Tabel 1. Tabel 1 menunjukkan bahwa secara keseluruhan persepsi petani terhadap sosialisasi AUTP kurang baik, dengan skor rata-rata sebesar 3,28. Persepsi petani mengenai keikutsertaan petani dalam kegiatan sosialisasi AUTP kurang baik. Hal ini juga terlihat dari point persepsi petani tentang semua informasi AUTP diperoleh dari sosialisasi AUTP yang juga kurang baik.Artinya dalam kegiatan sosialisasi AUTP selama ini banyak tidak melibatkan petani, dan kegiatan sosialisasi tidak efektif memberikan informasi AUTP kepada petani. Dilihat dari persepsi frekuensi sosialisasi, memiliki skor 2,97 yang berarti kurang baik. Artinya frekuensi sosialisasi yang dilakukan selama ini tidak tepat dalam memenuhi kebutuhan petani.

Tabel 2 menunjukkan bahwa rata-rata total skor untuk variabel manfaat AUTP adalah kurang baik. Dua dari empat pernyataan tentang manfaat AUTP

Tabel 2. Persepsi Petani terhadap AUTP Berdasarkan pada Variabel Sosialisasi

\begin{tabular}{|c|c|c|c|c|c|c|c|c|c|}
\hline \multirow[b]{2}{*}{ No } & \multirow[b]{2}{*}{ Pernyataan } & \multicolumn{7}{|c|}{ Jawaban } & \multirow[b]{2}{*}{$\begin{array}{l}\text { Rata- } \\
\text { rata } \\
\text { skor }\end{array}$} \\
\hline & & SS & $\mathbf{S}$ & $\mathbf{R R}$ & TS & STS & Total & $\begin{array}{l}\text { Total } \\
\text { Skor }\end{array}$ & \\
\hline \multicolumn{10}{|c|}{ Sosialisasi AUTP } \\
\hline 1 & $\begin{array}{l}\text { Saya mengikuti sosia lisa si terlebih dahulu } \\
\text { mengenai AUTP sebelum mendaftar se bagai } \\
\text { peserta AUTP }\end{array}$ & 0 & 21 & 7 & 7 & 0 & 35 & 119 & 3,40 \\
\hline 2 & $\begin{array}{l}\text { Saya memperoleh semua informasi men genai } \\
\text { AUTP dari sosia lisa si yang diberikan }\end{array}$ & 0 & 14 & 14 & 7 & 0 & 35 & 112 & 3,20 \\
\hline 3 & $\begin{array}{l}\text { Sosialisasi sangat bermanfaat untuk } \\
\text { meningkatkan pengetahuan saya mengenai } \\
\text { AUTP }\end{array}$ & 0 & 19 & 13 & 2 & 1 & 35 & 124 & 3,54 \\
\hline 4 & $\begin{array}{l}\text { Frekuensi sosialisasi yang dila kukan su dah } \\
\text { sesuai dengan kebutuhan dan harapan saya }\end{array}$ & 0 & 11 & 12 & 12 & 0 & 35 & 104 & 2,97 \\
\hline & Rata-rata total skor & & & & & & & 114,75 & 3,28 \\
\hline
\end{tabular}




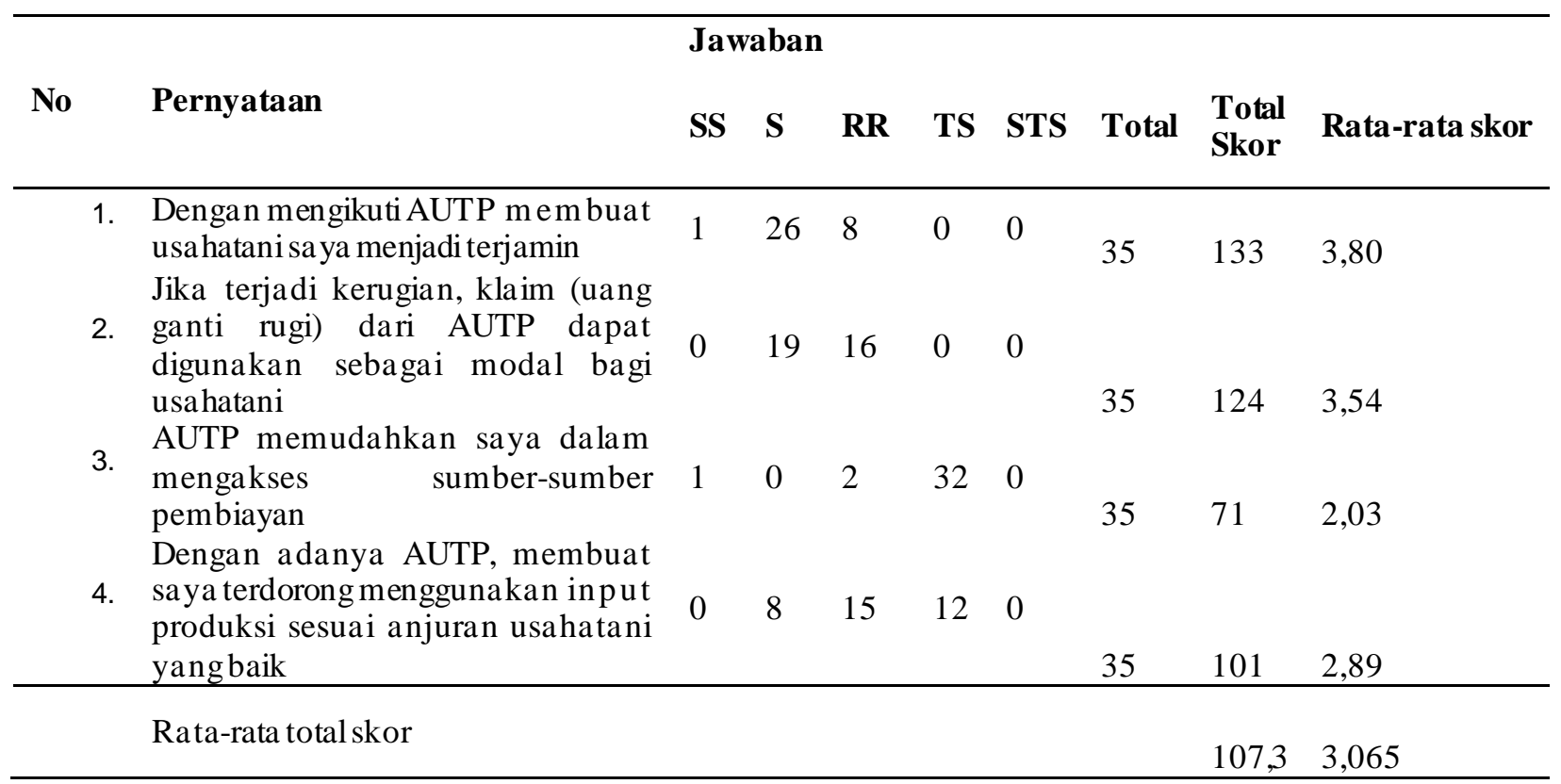

memiliki skor dengan kategori kurang baik, dan 2 pernyataan yang memiliki skor dengan kategori baik, yaitu pernyataan tentang manfaat mengikuti AUTP akan membuat usaha tani petani lebih terjamin yang memiliki kategori baik dan pernyataan tentang jika terjadi kerugian, klaim (uang ganti rugi) dari AUTP dapat digunakan sebagai modal bagi usahatani juga memiliki kategori baik. Artinya petani menyadari bahwa dengan mengikuti AUTP petani memperoleh manfaat dengan lebih terjaminnya usaha tani dan kelanjutan dari usaha taninya. Pernyataan tentang mengikuti AUTP akan memudahkan akses ke demikian juga dengan pernyataan dengan adanya AUTP, membuat saya terdorong menggunakan input produksi sesuai anjuran usahatani yang baik.

Tabel 3 menunjukkan bahwa rata-rata skor tentang potensi AUTP adalah baik. Pernyataan tentang petani akan mendaftar kembali menjadi peserta AUTP pada periode musim tanam berikutnya adalah kurang baik dengan skor 3,37. Sebanyak 22 orang responden atau sebesar 62,85 persen menjawab raguragu dan hanya sebanyak 13 orang responden atau 37,14 persen petani yang setuju untuk mendaftar kembali pada periode tanam berikutnya. Hal ini

Tabel 3. Persepsi Petani terhadap AUTP Berdasarkan pada Variabel Potensi AUTP

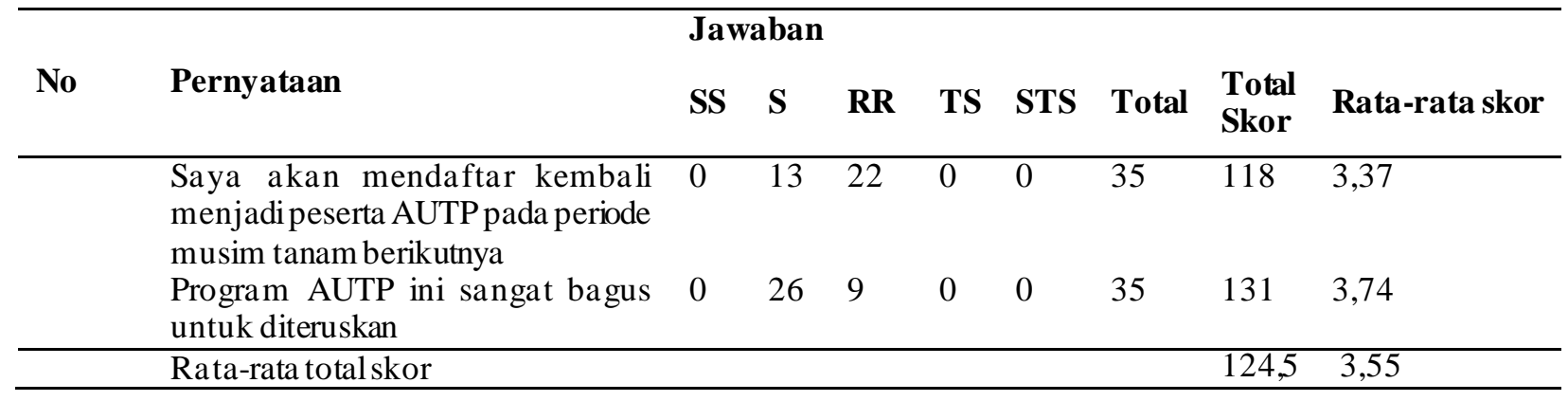

sumber pembiayaan lainnya adalah kurang baik DOI:10.25077/joseta.v2i2.240 menunjukkan bahwa petani masih belum melihat

Yenny Oktavia 181 
manfaat dari AUTP ini, sehingga keputusan untuk berpartisipasi lebih lanjut masih diragukan. Hal ini juga disebabkan karena petani banyak yang belum merasakan manfaat klaim AUTP, dan hanya membayar premi saja selama ini. Tabel 3. Persepsi Petani terhadap AUTP Berdasarkan pada Variabel Potensi AUTP

Persepsi tentang program AUTP ini sangat bagus untuk diteruskan memiliki kategori baik, dan pada umumnya petani setuju jika program ini dilanjutkan. Kondisi ini menunjukkan bahwa sebenarnya petani sudah menyadari tentang pentingnya AUTP untuk usaha tani mereka, namun karena ada beberapa mekanisme yang belum sesuai dengan kebutuhan petani, maka petani masih banyak yang ragu-ragu dalam melanjutkan untuk berpartisipasi dalam program AUTP ini.

Analisis Program AUTP dalam Perencanaan Komunikasi di Kabupaten Solok.

Perencanaan Komunikasi AUTP adalah upaya membuat rancangan pelaksanaan sosialisasi/ promosi AUTP kepada khalayak sasarannya dengan harapan tercapainya tujuan yang telah ditetapkan. Rancangan pelaksanaan komunikasi AUTP mulai dari perencanaan, pengorganisasian, pelaksanaan di lapangan hingga monitoring dan evaluasi (monev) kegiatan AUTP. Seperti dimaklumi, dalam setiap tindakan (program) komunikasi setidak-tidaknya terdapat tiga hal utama yang saling berkaitan. Pertama, sumber atau komunikator yang menyampaikan pesan yang terdapat dalam program komunikasi itu. Komunikator harus dipersiapkan dengan baik agar menunjang pada efektivitas AUTP. Kedua, khalayak baik individual, kelompok, ataupun organisasi yang menerima program. Sesuai segmentasinya, cara mensosialisasikan program kepada masing-masing kelompok khalayak pastilah berbeda sehingga harus disiasati dengan cermat; dan Ketiga, informasi AUTP yang akan disampaikan kepada khalayak. Struktur, jenis, dan cara menyampaikan berkaitan erat dengan dampak AUTP.
Menurut (Riffe, Lacy, Fico, \& Watson, 2019.) analisis konten dalam penelitian komunikasi sangat diperlukan, dapat digunakan untuk melihat efek komunikasi dan berbagai faktor yang mempengaruhi, baik dari karakteristik komunikator, individu, maupun kelembagaan. Selanjutnya (Cangara, 2013) mengatakan, terdapat dua hal lain yang penting dalam setiap bentuk program komunikasi. Pertama, saluran atau media yang dipakai guna menyampaikan pesan. Setiap jenis media memiliki keunggulan dan kelemahan masingmasing sehingga perlu dipikirkan dengan baik media apa yang akan dipergunakan dalam AUTP. Kedua, efek atau dampak yang ditimbulkan dalam perencanaan AUTP yang hasilnya sangat bergantung pada siapa yang menjadi komunikator, bagaimana dan kepada siapa pesan disampaikan, dan media apa yang dipergunakan. Aspek komunikasi tersebut sering dihimpun dalam model SMCRE, yaitu komunikator, pesan, dan penerima, bisa dipastikan selalu ada dalam setiap peristiwa komunikasi baik komunikasi antarpribadi, komunikasi kelompok, komunikasi organisasi, maupun komunikasi sosial. Apalagi dalam sebuah Perencanaan komunikasi AUTP yang memang didesain secara kreatif dan sistematis.

Mengacu pada siklus SOSTAC (Gambar 3), tahapan pra-desain adalah tahap melakukan analisis situasi (situation analysis). Analisis ini dilakukan untuk mengetahui situasi dan kondisi lapangan di mana AUTP akan dilaksanakan, dalam analisis situasi dilakukan tiga pendalaman yaitu sebagai berikut: Pertama, analisis "program"yang akan disosialisasikan yaitu AUTP. Kedua, analisis khalayak sasaran (target audience). Ketiga, analisis media informasi yang potensial dimanfaatkan untuk dalam mencapai tujuan. Untuk pembahasan kali ini dibatasi hanya pada analisis program AUTP. Menurut (Rasyid, Saleh, Cangara, \& Priatna, 2017) penelitian komunikasi dalam program CSR dapat dilakukan secara komprehensif, membahas tujuh elemen seperti, komunikator, pesan, komunikan, saluran, efek, umpan balik, dan lingkungan. 


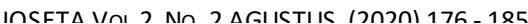

Tabel 4. Sebaran Peserta Program Asuransi Usahatani Padi (AUTP) di Kabupaten Solok Berdasarkan Sifat-Sifat Informasi AUTP

\begin{tabular}{|c|c|c|c|c|}
\hline No & Sifat-sifat Informasi Agribisnis & Kategori & $\begin{array}{l}\text { Jumlah } \\
\text { (Orang) }\end{array}$ & $\begin{array}{l}\text { Persentase } \\
(\%)\end{array}$ \\
\hline \multirow[t]{4}{*}{1.} & \multirow[t]{4}{*}{ Kua lita s program } & Rendah $(1,00-1,66)$ & 0 & 0 \\
\hline & & Sedang $(1,67-2,33)$ & 17 & 48,57 \\
\hline & & Tinggi $(2,34-3,00)$ & 18 & 51,43 \\
\hline & & Rerata(Sedang: $77,33 \%$ ) & & \\
\hline \multirow[t]{17}{*}{2.} & \multirow{5}{*}{$\begin{array}{l}\text { Pengemasan informasi } \\
\text { Relevansi Muatan Informasi }\end{array}$} & & & \\
\hline & & Rendah $(1,00-1,66)$ & 0 & 0 \\
\hline & & Sedang $(1,67-2,33)$ & 12 & 34,29 \\
\hline & & Tinggi $(2,34-3,00)$ & 23 & 65,71 \\
\hline & & Rerata (Tinggi: 84\%) & & \\
\hline & \multirow[t]{4}{*}{ Kreativitas informasi } & Rendah $(1,00-1,66)$ & 0 & 0 \\
\hline & & Sedang $(1,67-2,33)$ & 24 & 74,29 \\
\hline & & Tinggi $(2,34$ - 3,00) & 11 & 31,43 \\
\hline & & Rerata (Sedang:76\%) & & \\
\hline & \multirow[t]{4}{*}{ Keaktualan informasi } & Rendah $(1,00-1,66)$ & 0 & 0 \\
\hline & & Sedang $(1,67-2,33)$ & 26 & 72,29 \\
\hline & & Tinggi $(2,34-3,00)$ & 9 & 25,71 \\
\hline & & Rerata (Sedang: 76,67\%) & & \\
\hline & \multirow[t]{4}{*}{ Keseluruhan Skor (peubah) X5 } & Rendah $(1,00-1,66)$ & 0 & 0 \\
\hline & & Sedang $(1,67-2,33)$ & 17 & 48,57 \\
\hline & & Tinggi $(2,34-3,00)$ & 18 & 51,43 \\
\hline & & Rerata (Sedang: $77,33 \%$ ) & & \\
\hline
\end{tabular}

Komunikasi dalam CSR secara komprehensif dalam pemberdayaan masyarakat akan menghasilkan efek yang baik dan citra positif bagi perusahaan.

Analisis AUTP yang akan kita sosialisasikan sangat penting agar kita tahu persis kedudukan program kita di hadapan program- program sejenis yang pernah beredar. Keberhasilan peningkatan kapasitas pelaku usahatani padi sawah sangat tergantung dari kualitas informasi yang diperoleh. Sifat- sifat informasi AUTP adalah penilaian pelaku AUTP mengenai aspek- aspek informasi program yang menyajikan informasi AUTP, yang dapat diimplementasikan untuk mendukung kapasitas pelaku AUTP. Penyampaian informasi program AUTP berupa kegiatan sosialisasi yang diselenggarakan oleh Dinas Pertanian Kabupaten Solok bersama pihak Asuransi Jasindo yang ditujukan kepada kelompok-kelompok tani pelaku usahatani padi.

Hasil penelitian Tabel 5 menggambarkan penilaian pelaku AUTP terhadap sifat-sifat informasi yang meliputi kualitas program dan pengemasan informasi. Secara keseluruhan rerata sifat-sifat informasi program AUTP berada pada kategori sedang $(77,33 \%)$, yang direfleksikan oleh kualitas program yang tergolong sedang, demikian juga dengan pengemasan informasi program AUTP. Hasil penelitian menunjukkan bahwa sebagian besar penilaian pelaku program AUTP menganggap sifatsifat informasi program cukup baik, karena informasi yang diberikan cukup sesuai dengan kebutuhan dan relevan dengan permasalahan yang dihadapi petani.

Hasil wawancara menunjukkan bahwa program AUTP merupakan program yang bagus sebagai solusi untuk menanggulangi permasalahan petani seperti risiko gagal panen yang tidak dapat diprediksi, namun terdapat kendala dalam pelaksanaan program seperti masih kurangnya sosialisasi program sehingga program ini belum tersampaikan kepada seluruh petani dan terdapat ketentuan-ketentuan pada mekanisme program yang belum sesuai dengan keinginan petani. Artinya, program AUTP yang ada selama ini belum diiniasiasi dari sistem sosial masyarakat, khususnya petani, tujuan dan ketentuan program yang ada saat ini merupakan hasil ketetapan dari pemerintah bukan ketetapan dari petani. Sejalan dengan penelitian Nurdjaya (2017), implementasi komunikasi 
partisipatif dalam pengembangan manajemen sumber daya pertanian khususnya padi di yogyakarta juga dipengaruhi oleh faktor karakteristik kelompok tani, kualitas informasi, peran agen pengembangan, dukungan lingkungan dan pemanfaatan aset sosial.

Sebagian peserta AUTP mengatakan bahwa pendekatan program informasi juga belum dilakukan secara dialogis yang melibatkan partisipasi peserta AUTP agar berpartisipasi, terbangunnya interaksi yang aktif sehingga informasi dapat berfungsi sebagai sarana berbagi pengetahuan antar pemangku kepentingan. Hal ini menyebabkan program informasi yang diterima belum mampu membangkitkan kesadaran para petani akan manfaat program bagi usahatani mereka. Karena program AUTP merupakan program yang dibentuk oleh pemerintah, maka pihak Dinas Pertanian, Asuransi Jasindo, PPL dan ketua kelompok tani hanya dapat menyampaikan informasi mengenai program tanpa dapat melakukan diskusi terkait program itu sendiri karena ketentuan program berasal dari pusat.

Sejalan dengan hasil penelitian (Sulistiani, Sumardjo, Purnaningsih, \& Sugihen, 2017 ). strategi komunikasi dalam pengembangan energi sosial pemberdayaan komunitas di Papua bisa dilakukan melalui pendekatan komunikasi linier dan dialog. Komunikasi partisipatif pengembangan program pemberdayaan masyarakat melalui implementasi komunikasi dialogis antar pemangku kepentingan berdasarkan prinsip kesetaraan komunikasi, integrasi komunikasi dan saling ketergantungan komunikasi.

Informasi mengenai program AUTP yang disampaikan oleh Dinas Pertanian dan Asuransi Jasindo menggunakan Bahasa Indonesia yang baik dan benar, sederhana dan praktis, terstruktur dan sistematis, serta logis, sedangkan informasi yang diterima petani melalui PPL atau ketua kelompok tani biasanya menggunakan bahasa setempat yaitu Bahasa Minang yang tujuannya agar komunikasi dengan petani dapat lebih lancar dan dapat dengan mudah dipahami oleh petani. Menurut hasil wawancara dengan petani, terkadang informasi yang disampaikan di Dinas Pertanian cukup menarik karena informasi ditampilkan menggunakan power point, namun tidak semua petani yang diundang untuk menghadiri sosialisasi yang diadakan oleh Dinas Pertanian tersebut, namun dalam penyampaian informasi dilakukan oleh PPL atau ketua kelompok, informasi disampaikan secara langsung tanpa menggunakan alat peraga apapun, sehingga sebagian petani merasa bahwa penyajian informasi mengenai program AUTP dinilai kurang kreatif dan kurang menarik. Sesuai dengan (Oktavia, Muljono, Amanah, \& Hubeis, 2017) , rendahnya kapasitas pelaku agribisnis dipengaruhi oleh faktor: tingkat pemanfaatan informasi, mutu layanan informasi, kemampuan interaksi sosial, tingkat berpartisipasi, dan kemampuan beragribisnis. Faktor karakteristik media, mutu informasi, sifat- sifat informasi dan karakteristik pelaku agribisnis berpengaruh positif dan nyata pada perilaku komunikasi dalam pengembangan kapasitas pelaku agribisnis.

Terkait keaktualan informasi, sebagian besar petani merasa bahwa informasi AUTP ini sebaiknya disampaikan secara berulang untuk membangkitkan kesadaran petani akan manfaat program AUTP. Petani yang berusia $>50$ tahun biasanya kurang mampu menyimpan informasi dan sering lupa meskipun informasi tersebut sudah pernah diberikan, sehingga perlu dilakukan pengulangan informasi setidaknya tiap pertemuan anggota kelompok tani. Informasi yang disajikan mengenai program AUTP saat ini sudah dinilai cukup aktual dan tepat guna. Beberapa petani peserta AUTP yang menerima sosialisasi menyatakan bahwa informasi yang disajikan juga sudah lengkap, terutama petani yang menerima sosialisasi langsung dari Dinas Pertanian dan Asuransi Jasindo, informasi yang mereka terima lebih lengkap dan mereka juga bebas melakukan tanya jawab dengan sumber informasi tersebut. 


\section{KESIMPULAN DAN SARAN}

\section{Kesimpulan}

Persepsi petani terhadap sosialisasi AUTP dan manfaat AUTP adalah kurang baik, Artinya petani menyadari bahwa dengan mengikuti AUTP memperoleh manfaat dengan lebih terjaminnya usaha tani dan kelanjutan dari usaha taninya, namun petani belum meyakini bahwa jika mengikuti AUTP akan memudahkan akses ke sumber pembiayaan lainnya. Sedangkan, persepsi petani terhadap potensi AUTP adalah baik. Persepsi yang kurang baik terhadap sosialisasi, karena kegiatan sosialisasi yang dilakukan selama ini tidak mampu menginformasikan tentang AUTP dengan baik kepada petani.

Analisis komunikasi program AUTP secara keseluruhan berada pada kategori sedang $(77,33 \%)$, yang direfleksikan oleh kualitas program dan pengemasan informasi program AUTP. Informasi yang diberikan cukup sesuai dengan kebutuhan dan relevan dengan permasalahan yang dihadapi petani, namun sosialisasi program masih kurang. Program belum diinisiasi dari petani, dan penyajian informasi AUTP dinilai kurang kreatif dan kurang menarik. Terkait keaktualan informasi, program dinilai cukup aktual dan tepat guna, diharapkan disampaikan secara berulang untuk membangkitkan kesadaran petani akan manfaat program.

\section{Saran}

Untuk meningkatkan persepsi dan partisipasi petani terhadap AUTP, sosialisasi program perlu dilakukan secara rutin, menyajikan informasi secara lengkap agar pemahaman petani terhadap program AUTP semakin baik. Dalam perencanaan komunikasi melalui analisis program AUTP, diperlukan peningkatan kualitas program dan pengemasan informasi agar dapat diterima dan dimanfaatkan petani. Perlu penelitian perencanaan komunikasi AUTP lebih lanjut, melalui analisis khalayak sasaran program dan analisis media, agar menghasilkan perencanaan operasional, strategi dan model komunikasi yang efektif.

\section{UCAPAN TERIMA KASIH}

Tim peneliti mengucapkan terima kasih kepada para petani padi peserta AUTP di Kabupaten Solok, Dinas pertanian, pihak Asuransi Jasindo, yang telah bersedia menjadi responden penelitian. Ucapan terima kasih disampaikan pula kepada Universitas Andalas dan Fakultas Pertanian yang telah memberikan dana untuk pelaksanaan penelitian ini.

\section{DAFTAR PUSTAKA}

Azriani, Z., Usman, Y., \& Paloma, C. (2017). Kajian Pelaksanaan Asuransi Usaha Tani Padi di Kota Padang. Laporan Penelitian, Universitas Andalas, Fakultas Pertanian, Padang.

Cangara, H. (2013). Perencanaan dan Strategi Komunikasi. Jakarta: Raja Grafindo Persada.

Oktavia, Y., Muljono, P., Amanah, S., \& Hubeis, M. (2017). Communication Strategy In Developing The Capacity of The Actors of Agribusiness Of Freshwater Fisheries. International Journal of Research In Social Sciences, Vol. 14. No.1.

Ra syid, A., Sa leh, A., Cangara, A., \& Priatna, B. (2017). The Role Of Communication In Corporate Social Responsibility. International Journal of Re se arch In SocialSciences, Vol. 5, No.7.

Riffe, D., Lacy, S., Fico, F., \& Watson, B. (2019.). Analyzing Media Messages Using Quantitative Content Analysis In Research.

Sulistiani, I., Sumardjo, Purnaningsih, N., \& Sugihen. (2017 ). The Determinate Factors That Affect To Social Energy Development To Papua Community Empowerment In Indonesia. International Journal of Research In Social Sciences, Vol. 12, No.1.

Windahl, S., Benno, H. S., \& Jean, T. O. (1992). Using Communication Theory An Introduction to Planned Communication. London- California- New Delhi: Sage. 